DOI: 10.17707/AgricultForest.65.1.17

\author{
Fatima DAHLIA, \\ Cesar BENITO, Mohamed BOUSSAID ${ }^{1}$
}

\title{
GENETIC DIVERSITY OF FRUITS IN WILD JUJUBE (Ziziphus lotus L. DESF.) NATURAL POPULATIONS FROM ALGERIA
}

\begin{abstract}
SUMMARY
Fruits from natural populations of wild jujube (Ziziphus lotus L. Desf.) collected from Algeria were evaluated through morphological and molecular markers. The analysis of variance revealed very highly significant differences for all the morphological characters studied $(\mathrm{P}<0.001$ ) with coefficients of variation ranging from $7.57 \%$ to $31.84 \%$ indicating a strong variation between populations. The analysis of genetic diversity between Ziziphus lotus populations using 35 ISSR primers showed a moderate polymorphism (61.31\%), a polymorphism information content of 0.35 , a resolving power of 2.51 and a marker index of 0.79. Cluster analysis using SM model, classify the nine populations in two main clusters. This classification seems independent to climate change.
\end{abstract}

Keywords: Ziziphus lotus, genetic diversity, fruits, morphological markers, ISSR markers.

\section{INTRODUCTION}

Spontaneous plant resources are a source of primary interest for humans and their needs (Bouallala et al. 2014). Algeria has important species of trees and shrubs that the majority are undeveloped. Their fruits are an important part of human food consumption because of their richness in nutrients. However, there are some fruits that are little consumed because of their scarcity and ignorance of their nutritional quality. Among them, we chose to conduct a study on wild jujube fruit (Ziziphus lotus L. Desf.).

This perennial shrub (Maraghni et al. 2010) is of interest in rehabilitating degraded areas (Azam-Ali et al. 2006). It protects soil against erosion (Laamouri et al. 2008). This species show a high tolerance to drought and salinity (Liu and Zhao 2009; Sudhersan and Ashkanani 2009). It provides important habitat for animals and plants (Seigne 1985; Oliet et al. 2012; Nebih Hadj-Sadok et al. 2014). It is an important source of a many nutrients, phyto-chemical components and natural bio-actives substances (Tirado and Pugnaire 2005; Wojdyło et al. 2016). It is rich in minerals, carbohydrates, proteins and fatty acids (Abdeddaim

\footnotetext{
${ }^{1}$ Fatima Dahlia (Correspending author: fdahlia84@gmail.com), Mohamed Boussaid, Laboratory of plant physiology applied to soilless crops, Ibn Khaldoun University, BP 78 Zaâroura, Tiaret, 14000, ALGERIA; Cesar Benito, Laboratory of Molecular Genetics, Department of Genetics, Faculty of Biology, Complutense University of Madrid, SPAIN.

Notes: The authors declare that they have no conflicts of interest. Authorship Form signed online.
} 
et al. 2014; Hammia et al. 2015). Ziziphus lotus is, therefore, a genetic resource with universal value (Rais et al. 2017).

Called in Arabic "Sedra ", Ziziphus lotus is a shrub with gray and spiny stems, deciduous leaves and small yellow flowers (Maraghni et al. 2011). The edible fruit called " nbag " is a dark red drupe (c. 1-1.5 cm in diameter) at maturity (Azam-Ali, 2006; Wang et al. 2016). The pulp is soft and pleasant; it surrounds a bone nucleus, called stone, rather small, rounded and binocular (Couverciiel, 1839). It usually contains two seeds (c. $6 \times 5 \mathrm{~mm})$ (Nasri-Ayachi and Nabli 2009).

The natural range of the majority of jujube trees is between $20^{\circ}$ and $30^{\circ}$ latitude (Laamouri et al. 2008). Wild jujube occurs throughout the Mediterranean region (Regehr and El Brahli 1995; Azam-Ali et al. 2006) with low penetration into the northern Sahara: Morocco, Algeria, Tunisia, Libya and Egypt. It then reappeared in Yemen, on the island of Socotra, in the Middle East: Palestine, Syria, Turkey (Quezel and Santa 1963; Ghedira, 2013; Bakhtaoui et al. 2014) and south to the Arabian Peninsula (Duling et al. 1998). It is very abundant in Iran, China and South Korea (Adeli and Samavati 2015). In Algeria, the wild jujube is very common throughout the country except in the AlgerianConstantine tell (Quezel and Santa 1963).

Environmental variations, cultivar, cultivation methods and storage conditions influence strongly the fruit quality (Guo et al. 2016). The important geographical and climatic distribution of wild jujube is an indicator of the presence of a large genetic diversity for this species (Singh et al. 2007). Exploring biodiversity and estimating genetic diversity is important for evaluating, improving, conserving and using the genetic resources (Ai et al. 2014; Zhang et al. 2015; Wang et al. 2016). In order to recognize resistant genotypes with good fruit properties, identification of local cultivars becomes a priority (Ghazaeian 2015; Martins et al. 2015; Tatari et al. 2016). Thereby, several ways are used to measure genetic diversity, including morphological characteristics that determine strongly the agronomic value and facilitate the classification of plants. Morphological evaluation of genetic diversity is direct, inexpensive and easy to use (Zhang et al. 2015). Techniques such as allozyme or DNA analysis are also use to assess directly the genetic diversity at the molecular level (Mondini et al., 2009). Inter Simple Sequence Repeat (ISSR) technique provides a powerful tool for the investigation of genetic variation within species. Recent ISSR studies of natural populations have demonstrated the hyper-variable nature of these markers and their potential use for population-level studies (Ge et al. 2005).

However, there is little information available regarding the diversity of wild jujube across several environments in the world (González-Robles et al. 2016; Boussaid et al. 2018). For this purpose, a comparative study of several populations of wild jujube can give an overview of the morphological and molecular variations existing in this species. The aims of this study were to 
identify genetic diversity of fruit of nine populations of wild jujube existed in Algeria and classify them using morphological and molecular characters.

\section{MATERIAL AND METHODS \\ Sampling and site characterization}

Fruits of Ziziphus lotus were harvested at maturity in August, September and October 2016. They were collected from nine stations in different regions of Algeria (table 1). Each station represents a population and each population was represented by 10 trees spaced of more than $10 \mathrm{~m}$.

The natural distribution area of harvested shrubs extends from $2^{\circ} 12 \mathrm{~W}$ to $4^{\circ} 18 \mathrm{E}$ longitude and from $32^{\circ} 1 \mathrm{~N}$ to $36^{\circ} 6 \mathrm{~N}$ latitude (table 1 ). This large area is characterized by climatic and soil variations covering the main bio-climatic stage of Algeria.

The sites of Ain Defla and Medea from the sub-humid stage have a moderate climate, with abundant and regular precipitations (773,62 and 807,23 $\mathrm{mm}$ ) and mild winter (table 1). The semi-arid stage that is under the effect of a continental climate is characterized by moderate rainfall (Chlef with $404.85 \mathrm{~mm}$ and Tiaret with $334.4 \mathrm{~mm}$ ), a cold winter and a hot summer.

Table 1: Description of the selected sites of the nine natural populations of Ziziphus lotus in Algeria.

\begin{tabular}{|c|c|c|c|c|c|c|c|c|c|}
\hline Populations & $\begin{array}{c}\text { Ain } \\
\text { Defla }\end{array}$ & Bechar & Chlef & El Bayadh & Ghardaia & Laghouat & M’Sila & Medea & Tiaret \\
\hline \multicolumn{10}{|c|}{ Position } \\
\hline Locations & $\begin{array}{l}\text { Ouled } \\
\text { Chikh }\end{array}$ & Mougheul & $\begin{array}{c}\text { Ouled } \\
\text { Ziad } \\
\end{array}$ & Bougtoub & Metlili & $\begin{array}{c}\text { Oued } \\
\text { Nogued } \\
\end{array}$ & Maarif & Boghar & Tidda \\
\hline Long & $2^{\circ} 1^{\prime} \mathrm{E}$ & $2^{\circ} 12^{\prime} \mathrm{W}$ & $1^{\circ} 6^{\prime} \mathrm{E}$ & $0^{\circ} 7^{\prime} \mathrm{E}$ & $3^{\circ} 33^{\prime} \mathrm{E}$ & 2०59'E & $4^{\circ} 18^{\prime} \mathrm{E}$ & $2^{\circ} 42^{\prime} \mathrm{E}$ & $1^{\circ} 14^{\prime} \mathrm{E}$ \\
\hline Lat $(\mathrm{N})$ & $36^{\circ} 6^{\prime}$ & $32^{\circ} 1^{\prime}$ & $36^{\circ} 6^{\prime}$ & $33^{\circ} 59^{\prime}$ & $32^{\circ} 18$ & $33^{\circ} 49^{\prime}$ & $35^{\circ} 22^{\prime}$ & $35^{\circ} 57^{\prime}$ & $35^{\circ} 40^{\prime}$ \\
\hline Alt ( & 516 & 1023 & 106 & 1038 & 526 & 772 & 410 & 853 & 705 \\
\hline \multicolumn{10}{|c|}{ Climate } \\
\hline Tm & 19.1 & 22.5 & 20.5 & 20.2 & 23.2 & 20.1 & 21.7 & 16.5 & 15.7 \\
\hline TR & 10.2 & 13.8 & 12.6 & 13.4 & 12.2 & 13.3 & 13 & 8.8 & 14.5 \\
\hline Dt & 28.1 & 37.8 & 31 & 35.3 & 33.9 & 37.1 & 36.3 & 28.4 & 35.8 \\
\hline $\mathrm{P}$ & 807.23 & 107.95 & 404.85 & 218.65 & 17.51 & 198.2 & 172.21 & \begin{tabular}{|l|}
773.62 \\
\end{tabular} & 334.03 \\
\hline Cliamte & Subhumid & Saharian & Semiarid & Arid & Saharian & Saharian & Arid & Subhumid & Semiarid \\
\hline \multicolumn{10}{|c|}{ Soil } \\
\hline $\mathrm{CaCo}_{3} \%$ & 3.5 & 7.5 & 24 & 19.1 & 4.11 & 8.8 & 24.97 & 0 & 2.6 \\
\hline OM \% & 1.51 & 0.49 & 1.2 & 1 & 0.75 & 0.78 & 2.01 & 1.3 & 0.92 \\
\hline $\mathrm{pH}$ & 8 & 7.85 & 7.9 & 7.8 & 8.4 & 7.97 & 8.61 & 6.5 & 7.88 \\
\hline Clay \% & 31 & 0.96 & 27 & 9.8 & 0.4 & 9.4 & 9.76 & 34.4 & 12.3 \\
\hline Silt \% & 50.6 & 16.62 & 46.8 & 43.6 & 8.6 & 16.73 & 13.68 & 39.9 & 38.8 \\
\hline Sand \% & 18.4 & 82.42 & 26.2 & 46.6 & 91 & 73.87 & 76.56 & 25.7 & 48.9 \\
\hline Soils & $\begin{array}{l}\text { Loamy } \\
\text { clay }\end{array}$ & $\begin{array}{l}\text { Sandy- } \\
\text { loam }\end{array}$ & $\begin{array}{l}\text { Clay- } \\
\text { loam }\end{array}$ & $\begin{array}{l}\text { Sandy- } \\
\text { loam }\end{array}$ & Sandy & \begin{tabular}{|l|} 
Sandy- \\
loam
\end{tabular} & $\begin{array}{l}\text { Sandy- } \\
\text { loam }\end{array}$ & \begin{tabular}{|l|} 
Clay- \\
loam
\end{tabular} & Loam \\
\hline
\end{tabular}

TM : annual mean temperature $\left({ }^{\circ} \mathrm{C}\right)$; TR : Temperature range $\left({ }^{\circ} \mathrm{C}\right)$; Dt : difference in temperatures between the hottest and the coolest months $\left({ }^{\circ} \mathrm{C}\right) ; \mathrm{P}$ : annual precipitation (mm);; OM : organic matter ; $(\mathrm{M}-\mathrm{m})$ : temperature differences between the hottest month and the coldest month 
In the arid zone, provenances of Msila, Laghoat and El Bayadh are influenced by the local arid steppe climate characterized by little rainfall throughout the year (172.21 to $218.65 \mathrm{~mm}$ ). The sites of Ghardaia and Bechar from the Saharean stage are characterized by very rare rainfall (17.5 to 107.95 $\mathrm{mm}$ ), a mild winter, a very hot summer and an arid climate.

Similarly, the soils of the different sites are very variable with a dominance of sandy soils in the arid and Saharan regions. Soils of sub-humid and semi-arid sites vary between clay-loamy and sandy-loamy (table 1). $\mathrm{pH}$ of the different soils is neutral to slightly alkaline (6.5 to 8.61 ). The levels of organic matter range from 0.48 to $2.01 \%$ and the $\mathrm{CaCO}_{3}$ levels vary from 0 to $24.97 \%$.

\section{Morphological traits}

Observations were performed on the mature fruit ready for harvesting. Immature fruits that have not attained their full sizes and that are predominantly green and quite hard in texture was not considered in this study. The colors of fruits and stones were determined using the Royal Horticultural Society color chart. The number of seeds, shapes of fruits and stones and srones appearences were also recoreded according to jujube descriptor. Determination of lengths and widths of fruits, pulps, stone and seeds were carried by using a digital caliper. A precision balance was used to measure the weight of fruits, pulps, stone and seeds.

\section{Chromosome number}

Chromosome number counting was performed according to the method of (Jahier et al. 1992). The mitosis was stopped by keeping roots in ice distilled water for 24 hours. Plant material was immersed in the Shift reagent for 90 minutes. The colored meristematic zone was isolated and placed between Glass slides and cover-slip in a few drops of Carmen's red reagent. The observation was made on a photonic microscope equipped with a digital camera connected to a microcomputer.

\section{Molecular analysis}

DNA extraction

A total of 45 plants (Five plants from each population) were used to extract DNA which was extracted using the NZY Plant/Fungi gDNA Isolation kit (Prates, 2014). Up to $20 \mathrm{mg}$ of fresh leaves were homogenized and used to extract DNA following the protocol. The genomic DNA was stored at $-20^{\circ} \mathrm{C}$.

\section{PCR amplification}

Thirty-five ISSR's markers were used as shown in (Table 4). Standard PCRs buffer were performed using NZYTaq $2 \times$ Green Master Mix. Each PCR reaction contained $10 \mu \mathrm{L}$ of NZYTaq $2 \times$ Green Master Mix, $1 \mu \mathrm{L}$ from each primer, $30 \mathrm{ng}$ DNA template and nuclease ( $3 \mu \mathrm{L}$ of $10 \mathrm{ng} / \mu \mathrm{L}$ ) and $6 \mu \mathrm{L}$ of free water to obtain a volume of $20 \mu \mathrm{l}$. Cycling procedure was run using PTC-100 thermocycler (MJ Research, Inc.) as follows: Initial denaturation at $94^{\circ} \mathrm{C}$ for five minutes followed by 45 cycles of denaturation at $94^{\circ} \mathrm{C}$ for 30 seconds, annealing temperature of $52^{\circ} \mathrm{C}$ for 45 seconds and extension at $72^{\circ} \mathrm{C}$ for two minutes and final extension at $72^{\circ} \mathrm{C}$ for six minutes. The amplification products were 
analyzed by electrophoresis in 1,2\% agarose in TAE buffer stained by $6 \mu \mathrm{L}$ of ethidium bromide and photographed under UV.

\section{Data analysis}

The partition of the variance was estimated between populations by the statistical analysis of the variance (ANOVA) using the Type III of SPSS for Windows version 16.0 for the calculation of the sums squares. Homogeneous groups are separated by Tukey test using the same software. The agglomerative hierarchical clustering procedure was based on Ward's method.

Data from ISSR markers analysis was scored for presence (1) and absence (0) of bands. Unclear bands were not counted. Dividing the number of polymorphic bands over the total number of bands gives an estimation of the polymorphism percentage.

The evaluation of the discriminatory power of the ISSR markers was done by means of three parameters: (i) Polymorphic information content (PIC) which is the probability in detecting polymorphism by a primer or primer combination between two randomly drawn genotypes, it was calculated using the formula PIC $=\mathbf{1}-\Sigma \boldsymbol{p}_{\boldsymbol{i}}{ }^{2}$, where $p_{i}$ is the frequency of the $i^{\text {th }}$ allele (Sehgal et al. 2009; Lamare and Rao 2015); (ii) Resolving power (Rp) which is the ability of each primer to detect level of variation between individuals, it was calculated as $\mathbf{R p}=\boldsymbol{\Sigma} \mathbf{I}_{\mathbf{b}}$ where $\mathrm{I}_{\mathrm{b}}$ (band informativeness) takes the values of: $\mathbf{1}-[\mathbf{2}|\mathbf{0 . 5}-\boldsymbol{p}|]$, where $p$ is the proportion of individuals containing the band (Prevost and Wilkinson 1999; Lamare and Rao 2015), and (iii) marker index (MI) in order to characterize the capacity of each primer to reveal or detect polymorphic loci among the genotypes, as a product of two functions - the polymorphic information content and effective multiplex ratio (EMR) (Milbourne et al. 1997; Varshney et al. 2007; Lamare and Rao 2015) : MI = PIC $\times$ EMR.

A dendrogram was constructed based on the simple matching coefficient (SM) and the UPGMA (unweighted pair-group method with arithmetic averages) cluster method with the program NTSYSpc (Numerical Taxonomy and Multivariate Analysis System version 2.1). A pair-wise difference matrix between genotypes was determined using SM coefficient to measure the resulting phenotic groups and the original matrix was bootstrapped 1000 times by employing Winboot to group the genotypes into discrete clusters.

\section{Morphological variability}

\section{RESULTS}

Analysis of variance show a very high inter-population variation justified by a very highly significant difference $(\mathrm{P}<0.001)$ between the populations for all morphological traits (table 2). Furthermore, there were no significant differences ( $\mathrm{P}>0.05$ ) between individuals in the same population (intra-population variation).

The fruits of wild jujube were characterized by a variation of the fruit color. Four colors were recorded for all populations (table 2): yellowish $(0.11 \%)$, brown (52.44\%), light brown (17.55\%) and dark brown (29.88\%). An intra- 
population variability characterized by the heterogeneity in the distribution of the coloration was noticed. The populations of Laghouat, Ain Defla and El Bayadh were homogeneous and characterized by a single fruit color. Whereas the other populations presented the heterogeneity for this trait because they were characterized by several fruit colors within the same population.

An inter-population variation for the shape of fruit was also observed: the elongated shape $(6,77 \%)$ and the round shape $(93,23 \%)$. Two populations which were heterogeneous and characterized by the presence of the two shapes of fruit at varying percentages (table 2). These populations are Bechar and M'sila

Table 2. Qualitative traits characterization of fruit in Algerian natural populations of Ziziphus lotus

\begin{tabular}{|c|c|c|c|c|c|c|c|c|c|}
\hline Populations & $\begin{array}{l}\text { Ain } \\
\text { Defla }\end{array}$ & Bechar & $r$ Chlef & El Bayed & Ghardaia & Laghouat & t Médéa & M'Sila & Tiaret \\
\hline \multicolumn{10}{|c|}{$\begin{array}{l}\text { Fruit colors } \\
\end{array}$} \\
\hline Yellowish & 0 & 0 & 0 & 0 & 2 & 0 & 0 & 0 & 0 \\
\hline $\begin{array}{l}\text { Brown } \\
\text { Light }\end{array}$ & 100 & 42 & 96 & 0 & 10 & 100 & 56 & 6 & 61 \\
\hline brown & 0 & 3 & 1 & 0 & 1 & 0 & 28 & 94 & 31 \\
\hline $\begin{array}{l}\text { Dark } \\
\text { brown }\end{array}$ & 0 & 53 & 3 & 100 & 87 & 0 & 16 & 0 & 8 \\
\hline & \multicolumn{9}{|c|}{ Fruit shape } \\
\hline Oval & 0 & 3 & 0 & 0 & 0 & 0 & 0 & 49 & 0 \\
\hline \multirow[t]{2}{*}{ Round } & 100 & 97 & 100 & 100 & 100 & 100 & 100 & 51 & 100 \\
\hline & \multicolumn{9}{|c|}{ Stone appearance } \\
\hline Smooth & 9 & 63 & 7 & 9 & 0 & 80 & 46 & 37 & 14 \\
\hline \multirow[t]{2}{*}{ Rough } & 91 & 37 & 93 & 91 & 100 & 20 & 54 & 63 & 86 \\
\hline & \multicolumn{9}{|c|}{ Stone shape } \\
\hline Elongated & 23 & 91 & 79 & 81 & 87 & 55 & 79 & 99 & 80 \\
\hline \multirow[t]{2}{*}{ Round } & 77 & 9 & 21 & 19 & 13 & 45 & 21 & 1 & 20 \\
\hline & \multicolumn{9}{|c|}{ Stone color } \\
\hline $\begin{array}{l}\text { Light } \\
\text { brown }\end{array}$ & 87 & 65 & 100 & 62 & 65 & 72 & 3 & 63 & 92 \\
\hline \multirow[t]{2}{*}{ brown } & 13 & 35 & 0 & 38 & 35 & 28 & 97 & 37 & 8 \\
\hline & \multicolumn{9}{|c|}{ Seed number } \\
\hline $\begin{array}{l}\text { One seed } \\
\text { Two }\end{array}$ & 74 & 72 & 47 & 59 & 69 & 59 & 76 & 41 & 56 \\
\hline seeds & 26 & 28 & 53 & 41 & 31 & 41 & 24 & 59 & 44 \\
\hline
\end{tabular}


There were an inter-population variation for the coloration of the stone. Two colors were observed: brown (32.33\%) and light brown (67.67\%). Only the population of Chlef was homogeneous and characterized by the presence of a single coloration of stone (light brown). In the other populations, the presence of the two colors of the stone was observed at various percentages (table 2).

The wild jujube showed an inter-population variation for the trait shape of the stone. Two forms were observed: the elongated shape (74.89\%) and the round shape (25.11\%). All populations were heterogeneous and presented the two stone shapes at various percentages (table 2).

Two stone's appearance were recorded smooth $(29,44 \%)$ and rough (70,56\%). Only the population of Ghardaia was homogeneous and characterized by rough appearance. In the other populations, the presence of the two appearancs of stone was recorded at various percentages (table 2).

Most wild jujube fruits had one seed per stone (61.44\%). Only $38.56 \%$ of the fruit had two seeds per stone. All populations were heterogeneous (table 2) and presented various percentages of seed number per stone.

Regarding fruit characterization (Table 3), it's shown that the population of Chlef has the highest values for fruit length $(12.979 \pm 0.717 \mathrm{~mm})$, wight $(13.503$ $\pm 0.822 \mathrm{~mm})$ and weigh $(0.871 \pm 0.134 \mathrm{~g})$. While the population of Ghardaia is chharacterised by the lowest values for these traits (11.166 $\pm 0.915 \mathrm{~mm} ; 11.223 \pm$ $0.884 \mathrm{~mm}$ and $0.464 \pm 0.107 \mathrm{~g}$ respectively). These two populations have grown in very different environments, which suggests that this character can be influenced by the environment. Fruit length, wight and weigh of the other populations varied between these two extremes.

The pulp length and width vary between $2.776 \pm 0.571 \mathrm{~mm}$ to $3.767 \pm$ $0.767 \mathrm{~mm}$ and between $3.874 \pm 0.879 \mathrm{~mm}$ to $5.134 \pm 0.694 \mathrm{~mm}$ respectively. The population of Medea has shown the highest pulp length and the population of Chlef has the highest pulp width. These traits seem to be independent of the environmental effect because the values showed no relationship with environmental variation. On the other hand, the pulp weight was very related to the variations of the environment. The populations of Chlef, Medea and Ain Defla growing in favorable areas had the highest values of pulp weights $(0.477 \pm$ $0.1 \mathrm{~g} ; 0.381 \pm 0.074 \mathrm{~g}$ and $0.377 \pm 0.091 \mathrm{~g}$ ). Whereas, the populations of Ghardaia, Laghouat and El Bayedh, growing in arid regions, had the lowest pulp weights (Table 3).

For stones, lengths varied from $8.225 \pm 0.847 \mathrm{~mm}$ (population of Ghardaia) to $10.062 \pm 0.641 \mathrm{~mm}$ (population of Chlef). The variations of this trait between populations seem to be independent of changes in the environment. Stones also exhibited wide variability for the trait width. The values (table 3) of the population of Ain Defla (humid climate) were the highest (8.838 \pm 0.913 $\mathrm{mm}$ ). The populations of Ghardaia and Laghouat (arid climate) had the lowest values $(7,156 \pm 0,687 \mathrm{~mm}$ and $7,188 \pm 0,747 \mathrm{~mm}$ respectively). Unlike the preceding trait, the width of stones seems to be correlated with environmental variations because wetland populations have the highest values. The weight 
stones varies from $0.225 \pm 0.057 \mathrm{~g}$ for the population of Ghardaia to $0.394 \pm$ 0.064 for the population of Chlef. It is clear that this trait is positively correlated with fruit and pulp weights.

Table 3: Inter-population variability of fruit characteristics of natural Zizyphus lotus in Algeria.

\begin{tabular}{|c|c|c|c|c|c|c|c|c|}
\hline Pop. & AinDefla & a Bechar & Chlef I & ElBayedh & Shardaia & Laghouat & Medea Msila & Tiaret CV \% \\
\hline & & & & Fruit ch & racteristi & & & \\
\hline FL (mm) & $12.09^{c}$ & $12.13^{\mathrm{c}}$ & $12.97^{\mathrm{d}}$ & $11.63^{d}$ & $11.16^{\mathrm{a}}$ & $11.19^{\mathrm{a}}$ & $12.59^{\mathrm{d}} 12.67^{\mathrm{d}}$ & $11.87^{\text {bc }} 7.572$ \\
\hline FW (mm) & $12.71^{\mathrm{d}}$ & $11.81^{\mathrm{bc}}$ & $13.50^{\mathrm{d}}$ & $11.75^{\mathrm{bc}}$ & $11.22^{\mathrm{a}}$ & $11.56^{\mathrm{b}}$ & $12.54^{\text {de }} 11.87^{\mathrm{d}}$ & $12.07^{\mathrm{cd}} 7.922$ \\
\hline Fwe (g) & $0.71^{\mathrm{e}}$ & $0.61^{\mathrm{cd}}$ & $0.87^{\mathrm{f}}$ & $0.58^{\mathrm{bc}}$ & $0.46^{\mathrm{a}}$ & $0.53^{\mathrm{b}}$ & $0.65^{\text {de }} 0.64^{d}$ & $0.62^{\text {cd }} 20.586$ \\
\hline & & & & Pulp ché & racteristi & & & \\
\hline PuL(mm) & $3.59^{\mathrm{d}}$ & $3.28^{c}$ & $2.91^{\mathrm{ab}}$ & $3.10^{\mathrm{bc}}$ & $2.94^{\mathrm{ab}}$ & $2.81^{\mathrm{a}}$ & $3.76^{\mathrm{d}} \quad 2.91^{\mathrm{ab}}$ & $2.77^{\mathrm{a}} \quad 20.732$ \\
\hline PuW(mm) & $3.87^{\mathrm{e}}$ & $4.47^{\mathrm{de}}$ & $5.13^{f}$ & $4.52^{\mathrm{bc}}$ & $4.06^{\mathrm{a}}$ & $4.37^{\mathrm{b}}$ & $4.86^{\mathrm{e}} \quad 4.29^{\text {cde }}$ & $4.23^{\mathrm{cd}} 18.858$ \\
\hline PuWe (g) & $0.37^{\mathrm{e}}$ & $0.36^{\mathrm{de}}$ & $0.47^{\mathrm{f}}$ & $0.31^{\mathrm{bc}}$ & $0.23^{\mathrm{a}}$ & $0.29^{\mathrm{b}}$ & $0.38^{\mathrm{e}} \quad 0.35^{\text {cde }}$ & $0.33^{\text {cd }} 27.036$ \\
\hline & & & & Stone ch & racterist & & & \\
\hline SL (mm) & $8.49^{\mathrm{ab}}$ & $8.84^{\text {cd }}$ & $10.06^{\mathrm{e}}$ & $8.52^{\mathrm{abc}}$ & $8.22^{\mathrm{a}}$ & $8.38^{a}$ & $8.82^{\text {bcd }} 9.75^{\mathrm{e}}$ & $9.10^{\mathrm{d}} \quad 8.521$ \\
\hline SW (mm) & $8.83^{e}$ & $7.33^{\mathrm{ab}}$ & $8.36^{\mathrm{d}}$ & $7.23^{\mathrm{a}}$ & $7.15^{\mathrm{a}}$ & $7.18^{\mathrm{a}}$ & $7.68^{\mathrm{c}} \quad 7.58^{\mathrm{bc}}$ & $7.83^{c} \quad 9.653$ \\
\hline SWe (g) & $0.33^{\mathrm{e}}$ & $0.24^{\mathrm{abc}}$ & $0.39^{f}$ & $0.26^{\mathrm{bc}}$ & $0.22^{\mathrm{a}}$ & $0.23^{\mathrm{ab}}$ & $0.27^{\text {cd }} \quad 0.29^{d}$ & $0.29^{\mathrm{d}} \quad 22.165$ \\
\hline & & & & Seed chr & racteristi & & & \\
\hline $\operatorname{SeL}(\mathbf{m m})$ & $5.38^{\mathrm{a}}$ & $5.75^{\mathrm{b}}$ & $5.88^{\mathrm{b}}$ & $5.50^{\mathrm{a}}$ & $5.43^{\mathrm{a}}$ & $5.36^{\mathrm{a}}$ & $5.51^{\mathrm{a}} \quad 5.95^{\mathrm{b}}$ & $5.83^{b} \quad 8.126$ \\
\hline $\operatorname{SeW}(\mathbf{m m})$ & $5.18^{\mathrm{c}}$ & $4.95^{\mathrm{ab}}$ & $4.98^{\mathrm{abc}}$ & $5.03^{\mathrm{bc}}$ & $4.82^{\mathrm{a}}$ & $4.78^{\mathrm{a}}$ & $5.51^{\mathrm{d}} \quad 4.94^{\mathrm{ab}}$ & $4.85^{\mathrm{ab}} \quad 9.077$ \\
\hline & & & & Chromos & ms numl & & & \\
\hline Chr Num & 24 & 36 & 24 & 36 & 36 & 24 & 24 & 24 \\
\hline $\begin{array}{l}\text { a,b,c indicat } \\
\text { at p value } \\
\text { length, Pu } \\
\text { SWe : Stor } \\
\text { coefficient }\end{array}$ & $\begin{array}{l}\text { W : Pu } \\
\text { ne weig }\end{array}$ & p width, & $\begin{array}{l}\text { fference } \\
\text { ruit leng } \\
\text { PuWe } \\
\text { : Seed le } \\
\text { hum }\end{array}$ & e : Pulp & ight, & $\begin{array}{l}\text { ous grou } \\
\text { h, FWe } \\
\text { : Stone } \\
\text { jidth, Se }\end{array}$ & $\begin{array}{l}\text { ups according } \\
: \text { Fruit weigh } \\
\text { length, SW : } \\
\text { eWe : Seed we }\end{array}$ & $\begin{array}{l}\text { to Tykey test } \\
\text { it, PuL : Pulp } \\
\text { Stone width, } \\
\text { eight, CV\% : }\end{array}$ \\
\hline
\end{tabular}

The seeds length character exhibits a high inter-population variation (table 3 ). The longest seeds were recorded in the populations of M'sila (5.953 \pm 0.477 $\mathrm{mm})$, Chlef $(5.888 \pm 0,437 \mathrm{~mm})$, Tiaret $(5.835 \pm 0.504 \mathrm{~mm})$ and Bechar $(5.752 \pm$ $0.576 \mathrm{~mm}$ ). Seed widths varied from $4.788 \pm 0.478 \mathrm{~mm}$ for the population of Laghouat to $5.516 \pm 0.373 \mathrm{~mm}$ for the population of Medea. The environment does not seem to have effects on these two traits, but the variation in seed weight is strongly influenced by environmental variation. This trait showed low values in the arid zones $(0.025 \pm 0.0079 \mathrm{~g}$ for the population of Laghouat and $0.030 \pm$ 0.0057 for the population of Bechar) compared with the values recorded in the 
populations that pushed in sub-humid environments $(0.0340 \pm 0.0035) \mathrm{g}$ for the population of Ain Defla.

Ward's method classified the nine natural populations of Ziziphus lotus L. by measuring the distance between the morphological characteristics to give rise to two closed clusters (figure 1).

The first cluster is represented by four populations: Bechar and El Bayadh which represent a subgroup and are very close. In this first cluster, we also find that the populations of Laghouat and Ghardaia. The commonality between these four populations is that they grow in arid environments that are characterized by high daily temperatures, high thermal amplitudes and low rainfall.

In the second cluster, there is a subgroup strongly linking the populations of M'sila and Tiaret which are populations of the semi-arid zones. The second cluster also includes the population of sub-humid areas: Medea, Ain Defla and Chlef.

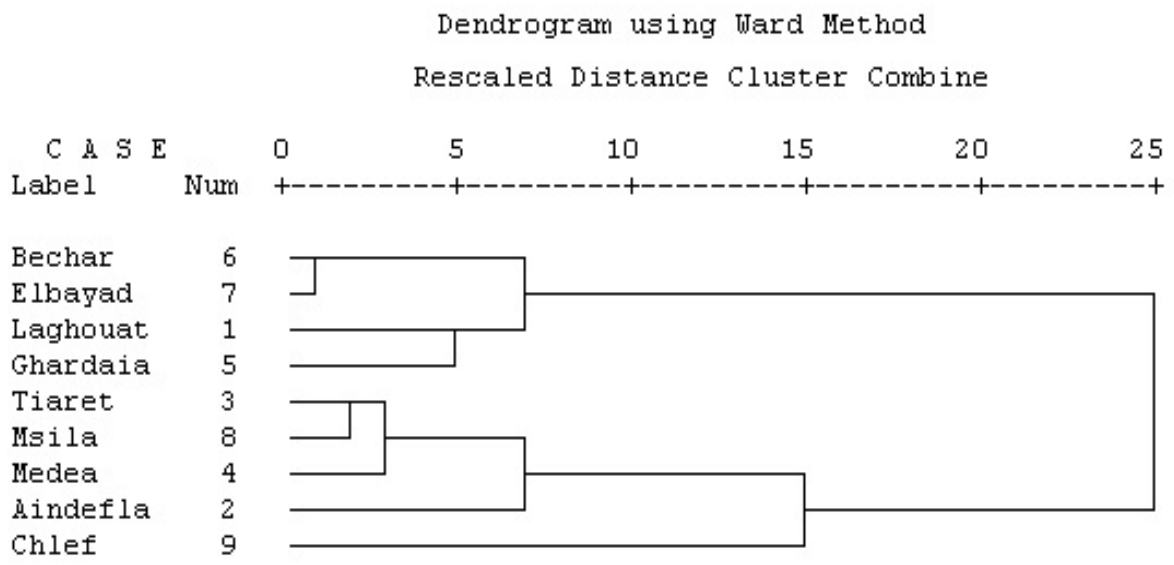

Fig 1. Dendrogram of grouping the nine natural populations of Ziziphus lotus L. produced using Ward method.

\section{Chromosoms number}

The number of chromosomes (Table 3) shows that wild jujube populations that grow in subhumid and semi-arid environments are diploid and have a chromosome number of $2 \mathrm{n}=2 \mathrm{x}=24$ chromosomes. Whereas the populations of arid zones (Bechar, El Bayadh, Ghardaia and M'sila) are triploid and have a number of chromosomes equal to $2 \mathrm{n}=3 \mathrm{x}=36$ chromosomes.

\section{Molecular analysis}

The total number of bands produced by the ISSR primers (TBN), the number of polymorphic bands (PB), the percentages of polymorphic bands (\% $\mathrm{P})$, the polymorphic information content (PIC), the resolving power (RP) and the marker index of the ISSR primers are shown in Table 4. 
The thirty-five ISSR primers tested produced a total of 274 amplified bands with an average of 7.82 bands per primer (MR). For these primers, the number of polymorphic bands was 168 (59.14\%) with an average of 4.8 polymorphic band per primer (EMR). The number of bands produced by each primer varied from 4 for the primers 847, 854, 864 and 869 to 14 for primers 812 and 876 . While the number of polymorphic bands produced by each primer has varied between 2 for the primers 814, 817, 846, 849, 864 and 897 to 14 for the primer 876. The percentage of polymorphism for each primer increased from 25 $\%$ for the primer 817 to $100 \%$ for the primers $813,876,892$ and 900 with an average of $59.14 \%$. The polymorphic information content (PIC) of ISSR primers among the populations of wild jujube varied between 0.08 for the primer 814 and 0.50 for the primer 855 with an average of 0.35 .

The resolving power (RP) has traded its minimum at the level of the primers 817 and 864 with a value of 0.44 and its maximum at the level of the primer 900 with a value of 8.67 . The average of the RP is 2.51 . At its hole, the marker index fluctuated between 0.15 for the primer 814 and 1.56 for the primer 813 with an average of 0.79 .

The ISSR markers from the 35 selected primers were used to construct a dendrogram using UPGMA cluster analysis and the simple matching coefficient (SM). The degree of similarity among wild jujube populations, from different locations, varied between $31.1 \%$ (between the populations of Laghout and Medea) and $95.7 \%$ (between the populations of M'sila and Tairet). Cluster analysis was done to group the populations into dendrogram (figure 2). This dendrogram has two clusters. The first cluster groups the populations from Ain Defla and Bechar with a similarity of $39.1 \%$. The second cluster groups the populations from the other regions. This second cluster can be subdivided into two sub-clusters, the first grouping six populations two by two.

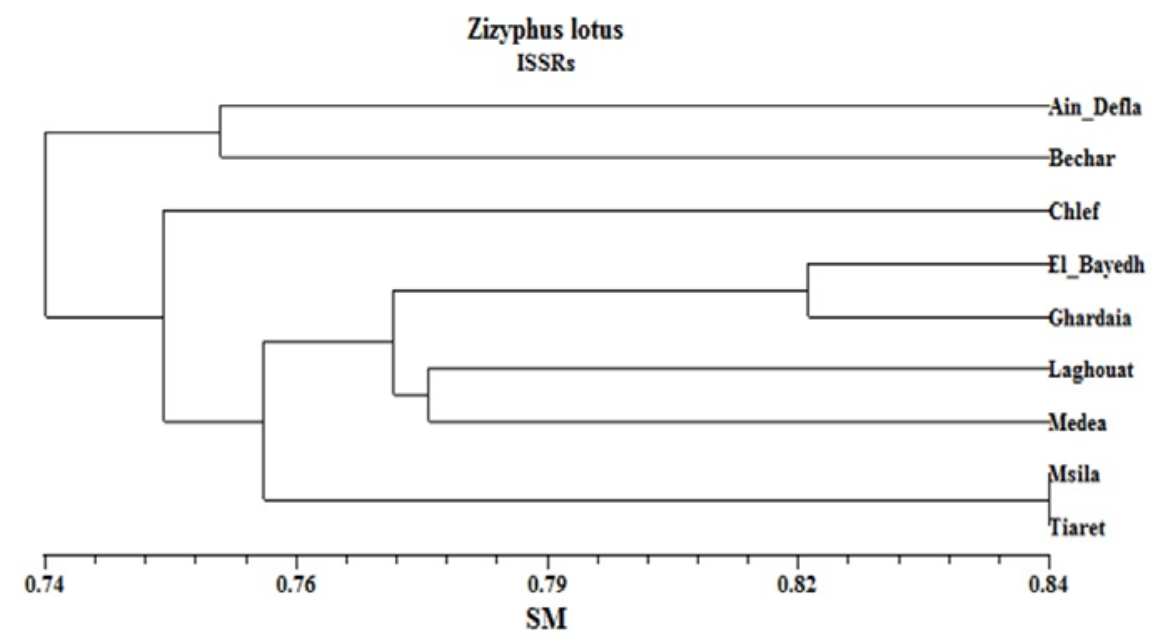

Fig 2 Dendrogram with the genetic relationship among 9 populations of $Z$. lotus growing in various regions in Algeria (SM coefficient and UPGMA method) 
Table 4: Details of amplified bands generated by 35 ISSR primers in 9 populations of $Z$. lotus

\begin{tabular}{|c|c|c|c|c|c|c|c|}
\hline Primer & 'Sequences 5' - 3' & TBN & PB & $\% \mathrm{P}$ & PIC & $\mathbf{R P}$ & MI \\
\hline 807 & $(\mathrm{AG})_{8} \mathrm{~T}$ & 8 & 3 & 37,50 & 0,44 & 1,56 & 0,55 \\
\hline 808 & $(\mathrm{AG})_{8} \mathrm{C}$ & 8 & 6 & 75,00 & 0,35 & 3,56 & 1,10 \\
\hline 810 & $(\mathrm{GA})_{8} \mathrm{~T}$ & 12 & 9 & 75,00 & 0,45 & 3,78 & 0,89 \\
\hline 811 & $(\mathrm{GA})_{8} \mathrm{C}$ & 10 & 3 & 30,00 & 0,21 & 2,00 & 0,31 \\
\hline 812 & $(\mathrm{GA})_{8} \mathrm{~A}$ & 14 & 10 & 71,43 & 0,36 & 4,89 & 1,23 \\
\hline 813 & $(\mathrm{CT})_{8} \mathrm{~T}$ & 6 & 6 & 100,00 & 0,49 & 2,00 & 1,56 \\
\hline 814 & $(\mathrm{CT})_{8} \mathrm{~A}$ & 7 & 2 & 28,57 & 0,08 & 1,11 & 0,15 \\
\hline 815 & $(\mathrm{CT})_{8} \mathrm{G}$ & 5 & 3 & 60,00 & 0,45 & 1,56 & 0,90 \\
\hline 817 & $(\mathrm{CA})_{8} \mathrm{~A}$ & 8 & 2 & 25,00 & 0,40 & 0,44 & 0,45 \\
\hline 823 & $(\mathrm{TC})_{8} \mathrm{C}$ & 8 & 5 & 62,50 & 0,27 & 2,00 & 0,87 \\
\hline 834 & $(\mathrm{AG})_{8} \mathrm{YT}$ & 6 & 3 & 50,00 & 0,22 & 1,78 & 0,58 \\
\hline 835 & $(\mathrm{AG})_{8} \mathrm{YC}$ & 9 & 4 & 44,44 & 0,48 & 2,44 & 0,63 \\
\hline 842 & $(\mathrm{GA})_{8} \mathrm{YG}$ & 9 & 6 & 66,67 & 0,31 & 3,11 & 0,96 \\
\hline 843 & $(\mathrm{CT})_{8} \mathrm{RA}$ & 10 & 5 & 50,00 & 0,32 & 3,11 & 0,86 \\
\hline 845 & $(\mathrm{CT})_{8} \mathrm{RG}$ & 7 & 5 & 71,43 & 0,40 & 3,11 & 1,02 \\
\hline 846 & $(\mathrm{CA})_{8} \mathrm{RT}$ & 6 & 2 & 33,33 & 0,12 & 1,33 & 0,25 \\
\hline 847 & $(\mathrm{CA})_{8} \mathrm{RC}$ & 4 & 3 & 75,00 & 0,17 & 1,33 & 0,76 \\
\hline 849 & $(\mathrm{GT})_{8} \mathrm{YA}$ & 8 & 5 & 62,50 & 0,37 & 3,33 & 0,87 \\
\hline 854 & $(\mathrm{TC})_{8} \mathrm{RG}$ & 4 & 2 & 50,00 & 0,23 & 0,89 & 0,63 \\
\hline 855 & $(\mathrm{AC})_{8} \mathrm{YT}$ & 8 & 4 & 50,00 & 0,50 & 2,44 & 0,69 \\
\hline 856 & $(\mathrm{AC})_{8} \mathrm{YA}$ & 10 & 7 & 70,00 & 0,12 & 4,22 & 0,52 \\
\hline 859 & $(\mathrm{TG})_{8} \mathrm{RC}$ & 6 & 4 & 66,67 & 0,46 & 2,22 & 0,76 \\
\hline 864 & $(\mathrm{ATG})_{6}$ & 4 & 2 & 50,00 & 0,40 & 0,44 & 0,90 \\
\hline 866 & $(\mathrm{CTC})_{6}$ & 8 & 7 & 87,50 & 0,49 & 2,22 & 1,48 \\
\hline 868 & $(\mathrm{GAA})_{6}$ & 6 & 4 & 66,67 & 0,27 & 2,00 & 0,62 \\
\hline 869 & $(\mathrm{GTT})_{6}$ & 4 & 3 & 75,00 & 0,42 & 2,00 & 1,04 \\
\hline 876 & $(\mathrm{GATA})_{2}(\mathrm{GACA})_{2}$ & 14 & 14 & 100,00 & 0,23 & 8,22 & 1,17 \\
\hline 881 & $\mathrm{G}_{3}\left(\mathrm{TG}_{4}\right)_{2} \mathrm{TG}$ & 5 & - & - & - & - & - \\
\hline 887 & $\operatorname{DVD}(\mathrm{TC})_{7}$ & 8 & 3 & 37,50 & 0,35 & 1,33 & 0,58 \\
\hline 888 & $\mathrm{BDB}(\mathrm{CA})_{7}$ & 8 & 4 & 50,00 & 0,32 & 1,56 & 0,77 \\
\hline 890 & $\operatorname{VHV}(\mathrm{GT})_{7}$ & 8 & 6 & 75,00 & 0,44 & 2,22 & 0,98 \\
\hline 891 & HVHTC(TG) $)_{6}$ & 10 & 4 & 40,00 & 0,46 & 1,56 & 0,65 \\
\hline 892 & $\begin{array}{l}\text { TAGATCTGATATCTGA }{ }_{2} \mathrm{~T}_{2} \\
\mathrm{C}_{3}\end{array}$ & 7 & 7 & 100,00 & 0,32 & 4,00 & 1,44 \\
\hline 897 & $\mathrm{C}_{2} \mathrm{GACTCGAGN}_{6} \mathrm{~A}(\mathrm{TG})_{2} \mathrm{G}$ & 6 & 2 & 33,33 & 0,12 & 1,33 & 0,25 \\
\hline 900 & $\mathrm{ACT}_{2} \mathrm{C}_{4} \mathrm{ACAG}_{2} \mathrm{~T}_{2} \mathrm{~A}_{2}(\mathrm{CA})_{2}$ & 13 & 13 & 100,00 & 0,23 & 8,67 & 1,17 \\
\hline \multirow{2}{*}{\multicolumn{2}{|c|}{$\begin{array}{l}\text { Total } \\
\text { Average }\end{array}$}} & 274 & & & & & \\
\hline & & $7,82^{\mathrm{MR}}$ & $\mathbb{R}_{\mathrm{R}}^{\mathbf{4} \mathbf{8}^{\mathrm{EM}}}$ & 59,14 & 0,35 & 2,51 & 0,79 \\
\hline
\end{tabular}

$\mathrm{N}=(\mathrm{A}, \mathrm{G}, \mathrm{C}, \mathrm{T}) ; \mathrm{R}=(\mathrm{A}, \mathrm{G}) ; \mathrm{V}=(\mathrm{A}, \mathrm{G}, \mathrm{C}) ; \mathrm{Y}=(\mathrm{C}, \mathrm{T}) ; \mathrm{B}=(\mathrm{C}, \mathrm{G}, \mathrm{T}) ; \mathrm{D}=(\mathrm{A}, \mathrm{G}, \mathrm{T}) ; \mathrm{H}=(\mathrm{A}, \mathrm{C}, \mathrm{T})$ 
The populations from Tiaret and M'sila appear to be the most similar at $95.7 \%$. The populations from El Bayadh and Ghardaia are grouped together with a similarity of $69.9 \%$ and the populations from Laghouat and Medea have a similarity of $31.1 \%$ between them. The population that is coming from Chlef represents the second sub-cluster and it seems different from the other six populations because it has a low degree of similarity with them (17.9\%).

\section{DISCUSSION}

Conservation and utilization of the native plant resources is essential for long-term sustainability of biodiversity. Wild native resources are adapted to specific and diverse environmental conditions. These adaptive features can be introduced into modern cultivars either through conventional breeding or advanced molecular genetic techniques (Riaz et al. 2011). Estimation of genetic diversity is important for conserving, evaluating and using genetic resources. It's useful for studying the diversity of different germplasm as possible sources of genes. That can improve the performance of cultivars, and for determining the uniqueness and distinctness of the phenotypic and genetic constitution of genotypes (Geleta et al. 2006).

Analysis of the morphological diversity of several natural populations of Ziziphus lotus belonging to various environmental conditions is of a great importance. It is the foundation of plant evolution and cultivar formation in the natural wide range of distribution of this species (Boussaid et al. 2018).

The analysis of morphological characters shows a very large divergence between the fruits, stones and seeds of Ziziphus lotus natural populations collected from several sites in Algeria. Populations from Chlef, Ain Defla and Medea are considered as the best populations morphologically. They are characterized by the higher lengths, widths and weights of the different parts of the fruit. While, the populations coming from Ghardaïa and Laghouat present the lowest values. The coefficients of variation ranged from $7.57 \%$ for fruit length to $27.036 \%$ for pulp weight. High coefficients of variation (more than 30\%) for Ziziphus jujuba ecotypes were recorded by Tatari et al. (2016) for number of thorns, annual thorn length, fruit weight, shape and width, as well as stone weight and size, indicating a large variation in these traits. Our results are also similar to those recorded by Saran et al. (2005) and Liu et al. (2009) who found high coefficients of variation for several traits, particularly for fruit weight, in Ziziphus mauritiana and Ziziphus jujuba genotypes respectively.

Fruit weight is considered as appropriate for the classification of jujube ecotypes (Tatari et al. 2016). The studies on the Iranian ecotypes of Ziziphus spina-christi showed a large-scale diversity among the genotypes that show considerable morphological variation which may affect these traits (Bina et al. 2012; Baghazadeh-Daryaii et al. 2017). Tatari et al. (2016) confirm that climatic conditions have a large effect on the morphological characters of the Ziziphus jujuba ecotypes. The plants of Ziziphus spina-christi grown at various altitudinal zonations in Saudi Arabia showed a response to climatic conditions by using 
altitudinal gradient (Moustafa et al. 2016). The evaluation of the morphological variability of 65 genotypes from Ziziphus genus (Z. nummularia, Z. spina-christi and Z. oxyphylla) in Iran, revealed a wide range of variation. They notified also that fruit weight among different species of jujube varied. This variation may depend on the cultivar and ecological conditions (Gao et al. 2011). Also, height differentiation among genotypes is caused by factors such as breeding system, isolation of population, seed and pollen dispersal distance (Norouzia et al. 2017). Exhibiting significant variability could be attributed to fact that the genotypes grow over a wide range of rainfall, temperature and soil type (Divakara and Das 2011).

Genetic diversity of plants based on morphological traits is difficult to measure in natural populations because these traits are influenced by environmental factors to a large degree (Riaz et al. 2011). To neutralize the environmental effect on the phenotypic expression among provenances for the purpose of breeding, this genetic resource should be compared under similar ecological conditions (Boussaid et al. 2018).

Molecular markers are widely used to assess genetic diversity and to study the relationships among genotypes and populations of many species. To study the genetic diversity of the genus Ziziphus, the ISSR, RADP, SSR, SRAP markers have been widely used on Ziziphus spina-christi (Alansi et al, 2016; Moustafa et al. 2016), Ziziphus mauritiana (Singh et al. 2007; Singh et al. 2014), Ziziphus jujuba (Li et al. 2010; Ma et al. 2011; Liu et al. 2014; Zhang et al. 2015;) and Ziziphus lotus (González-Robles et al. 2016). Our work is the first to study the molecular diversity between natural populations of Ziziphus lotus L. Desf through several environments in Algeria and the second in the world.

In order to resolve some of the inconveniences associated with RAPD (low reproducibility), the high AFLP cost, and the need to know the flanking sequences in order to developed primers for SSR polymorphism, ISSR were developed (Gomes et al. 2012). Also, the use of ISSR in this study is based on the fact that they are easy to employ and highly reproducible (Boussaid et al. 2010). Several studies have shown that the ISSR markers seem to be convenient for genetic diversity of Triticale (Tonk et al. 2014), Canarium album (Mei et al. 2017), Cajanus cajan (Hemalatha and Shanmugasundaram 2010) genotypes compared with RADP technique.

Our thirty-five ISSR primers yielded 274 bands, of which 168 were polymorphic. The percentage of polymorphism was $61.31 \%$. Our results are close to those found for other species: $61.54 \%$ for Ziziphus spina-christi (Moustafa et al. 2016), 57.3\% for Dioscorea hispida (Nudin et al. 2017) and $53.80 \%$ for Triticale (Tonk et al. 2014). However, these results remain low compared with those found by Singh et al. (2007) for Ziziphus mauritiana (89.96 \%), Alansi et al. (2016) for Ziziphus spina-christi (93.4\%) and Boussaid et al. (2010) for Stipa tenacissima (87.79\%).

The triploid populations of Ziziphus lotus showed the highest values of total bands number with 206 bands for the population of Bechar, 201 bands for 
the populations of M'sila and El Bayadh and 191 bands for the population of Ghadaia. These populations had also the highest values of polymorphic bands (100, 95, 95 and 85 bands respectively) and polymorphism percent (48.54\% for the population of Bechar and $47.26 \%$ for the population of El Bayadh and M'sila).

The averages obtained for polymorphism information content (PIC), resolving power (Rp) and the marker index (MI) are 0.35, 2.51 and 0.79 respectively. These averages are close to those found by Tonk et al. (2014) in triticale (PIC $=0.33$ and $\mathrm{Rp}=3.15$ ), by Lamare and Rao (2015) in Musa acuminata colla (PIC $=0.35, \mathrm{Rp}=2.34$ and $\mathrm{MI}=0)$, by Rashidi et al., (2013) in Medicago sativa (PIC $=0.26$ and $\mathrm{MI}=1.88$ ) and by Singh et al. $(2007)$ in Ziziphus mauritiana (PIC $=0.42$ and $\mathrm{Rp}=3.68$ ).

Ward's dendrogram for morphological traits and the clustering based on SM model from ISSR data have classified wild jujube populations differently. The methods of morphology are insufficient to distinguish cultivars and the results are often liable to be influenced by the environment. It has been proved that ber genotypes earlier reported to be similar based on morphology, are genetically different (Singh et $a l$. 2014).

The clustering of Ziziphus lotus populations according to the SM method seems independent of climatic variations. We found that the populations from M'sila and Tiaret are the most similar (95.79\%). These two populations have close latitudes ( $35^{\circ} 22 \mathrm{~N}$ and $35^{\circ} 57 \mathrm{~N}$ respectively). Similarly, populations from arid regions (El Bayadh and Ghardaïa) have a similarity of $69.90 \%$ and are triploids ( $2 \mathrm{n}=3 \mathrm{x}=36$ chromosomes). Populations from Laghouat and Medea, which have close longitudes ( $2^{\circ} 59 \mathrm{E}$ and $2^{\circ} 42 \mathrm{E}$ respectively) and which grew at the altitudes of $772 \mathrm{~m}$ and $853 \mathrm{~m}$ respectively, are classified together (31.10\%). While, the population from Ain Defla (sub-humid zone) and the population from Bechar (arid zone), which have a similarity of $39.10 \%$, seem independent from climatic and geographical conditions.

On their part, Rashidi et al. (2013) concluded that grouping of genotypes based on cluster analysis and principal coordinate analysis indicate that genetic variations of Medicago sativa do not agreement with the geographical distribution of genotypes. Ziziphus spina-christi showed a response to a suite of climatic conditions by using altitudinal gradients within circumscribed various localities in Saudi Arabia (Moustafa et al. 2016). A large diversity within populations was recorded in Ziziphus spina-christi which can be explained by the out crossing pollinisation phenomenon and a low value of genetic diversity among populations. Studies also shows that genetic variations occurred a long elevation gradient because topographical heterogeneity of plant habitat causes substantial changes in the improvement. And at different altitudes strong isolation of populations may occur due to drastic differences in phenology between higher and lower altitude and mountain barriers which restrict the gene flow between populations causing complex and varied genetic variation (Lamare and Rao 2015). 


\section{CONCLUSIONS}

Wild jujube (Ziziphus lotus L. Desf.), despite being a frequent species in Algeria, occupying various regions and ecosystems and with various interest, remains devalued because there are very few studies on this species. Through this study, we have evaluated the genetic diversity of Ziziphus lotus fruits from several localities covering all bio-climatic stages of Algeria, by using morphological and molecular markers. The analysis of the morphological results revealed a strong divergence between the different populations. They also showed that the environment had a considerable effect in the development of the phenotypes of the majority of the characters. ISSR data showed moderate genetic diversity between wild jujube populations. To valorize this study, the number of populations studied must be expanded, study the genetic diversity within populations and test other molecular markers that can give more effective results.

\section{ACKNOWLEDGEMENTS}

The laboratory of molecular genetic has been of great help for the realization of this work. I am grateful to all the professors and assistants of the Department of Genetics at the Complutense University of Madrid, Spain. I thank infinitely Dr Tomas Naranjo from the laboratory of cytogenetics (Complutense University of Madrid, Spain). As I thank Barouagui S., Bakiri N., Krimat M., Tabti L., Mahieddine S., for the help provided to collect the fruits of wild jujube from several zones.

\section{REFERENCES}

Abdeddaim, M. Lombarkia, O. Bacha, A. Fahloul, D. Abdeddaim, D. Farhat, R. Saadoudi, M. Noui, Y. \& Lekbir, A. (2014): Biochemical characterization and nutritional properties of Ziziphus lotus L. fruits in Aures region, Northeastern of Algeria. Annals: Food Science and Technology, 15: 75 - 81.

Ai, B. Kang, M. \& Huang, H. (2014): Assessment of Genetic Diversity in Seed Plants Based on a Uniform $\pi$ Criterion. Molecules, 19 : 20113-20127. https://doi: 10.3390/molecules191220113

Alansi, S. Tarroum, M. Al-Qurainy, F. Khan, S. \& Nadeem, M. (2016): Use of ISSR markers to assess the genetic diversity in wild medicinal Ziziphus spina-christi (L.) Willd. collected from different regions of Saudi Arabia. Biotechnology \& Biotechnological Equipment, 30(5): 942-947.

Azam-Ali, S. Bonkoungou, E. Bowe, C. DeKock, C. Godara, A. \& Williams, J.T. (2006): Fruits for the Future 2: Ber and other jujubes. Ed. Southampton Centre for Underutilised Crops, U.K., 302 p.

Baghazadeh-Daryaii, L. Sharifi-Sirchi, G.R. \& Samsampoor, D. (2017): Morphological, phytochemical and genetic diversity of Ziziphus spina-christi (L) Desf. in South and Southeastern of Iran. Journal of Applied Research on Medicinal and Aromatic Plants, https://doi.org/10.1016/j.jarmap.2017.06.006.

Bakhtaoui, F. Lakmichi, H. Megraud, F. Chait, A. \& Gadhi, C.E.A. (2014) : Gastroprotective, Anti-Helicobacter pylori and, Antioxidant Properties of Moroccan Ziziphus lotus L. Journal of Applied Pharmaceutical Science, 4 (10): 81-87. https://doi.org/10.7324/JAPS.2014.40115. 
Bina, F. Zamani, Z. \& Nazari, V. (2012) : Morph-based Genetic variation in Christ's thorn (Ziziphus spina-christi (L) Wild.). Iranian Journal of Rangelands Forest Plant Breeding and Genetic Research, 2 (38): 274-288.

Bouallala, M. Bradai, L. \& Abid, M. (2014): Diversité et utilisation des plantes spontanées du sahara septentrional algérien dans la pharmacopée saharienne: Cas de la région du Souf. Revue ElWahat pour les reherches et les études, 7(2) : 18-26. https://www.researchgate.net/publication/281526143

Boussaid, M. Benito, C. Kaid-Harche, M. Naranjo, T. \& Zedek M. (2010): Genetic Variation in Natural Populations of Stipa tenacissima from Algeria. Biochem Genet. https://doi10.1007/s10528-010-9367-7.

Boussaid, M. Taïbi, K. Ait Abderrahim, L. \& Ennajah, A. (2018): Genetic diversity of Ziziphus lotus natural populations from Algeria based on fruit morphological markers. Arid land research and management: 1 - 15: https://doi.org/10.1080/15324982.2018.1424742.

Couverciiel, (1839): Traité Des Fruits, Tant Indigènes Qu'exotiques, Dictionnaire Carpologique. Ed. Imprimerie Et Librairie De Bouchard-Hl'zard, Paris, France, : 223-224

Divakara, \& Das, R. (2011): Variability and divergence in Pongamia pinnata for further use in tree improvement. Journal of Forestry Research, 22(2): 193-200. https://doi10.1007/s11676-011-0149-9

Duling, D.W. Ghazanfar, S.A. \& Prendergast, H.D.V. (1998): A New Species of Ziziphus Mill. (Rhamnaceae) from Oman. Kew Bulletin, 53(3): 733-739. https://doi.org/ 10.2307/4110494.

Gao, Q.H. Wu, P.T. Liu, J.R. Wu, C.S. Parry, J.W. \& Wang, M. (2011): Physico chemical properties and antioxidant capacity of different jujube (Ziziphus jujuba Mill.) cultivars grown in loess plateau of China. Sci. Hortic., 130: 67-72. https://doi:10.1016/j.scienta.2011.06.005.

Ge, X.J. Yu, Y. Yuan, Y.M. Huang, H.W. \& Yan, C. (2005) : Genetic Diversity and Geographic Differentiation in Endangered Ammopiptanthus (Leguminosae) Populations in Desert Regions of Northwest China as Revealed by ISSR Analysis. Annals of Botany, 95: 843-851. https://doi:10.1093/aob/mci089

Gelata, M. Labuschgne, M.T. \& Viljoen, C.D. (2006): Genetic diversity analysis in sorghum germplasm as estimated by AFLP, SSR and morpho-agronomical markers. Biodiversity and Conservation, 15: 3251-3265. https://doi.org/10.1007/s10531-005-0313-7.

Ghazaeian, M. (2015): Genetic diversity of Jujube (Ziziphus jujuba Mill.) germplasm based on vegetative and fruits physicochemical characteristics from Golestan province of Iran. Comunicata Scientiae, 6(1): 10-16.

Ghedira, K. (2013): Ziziphus lotus (L.) Desf. (Rhamnaceae) : jujubier sauvage. Phytothérapie, 11 : 149-153. https://doi.org/10.1007/s10298-013-0776-8.

Gomes, S. Martins-Lopes, P. \& Guedes-Pinto, H. (2012) : Chapter 2 : Olive Tree Genetic Resources Characterization Through Molecular Markers. In : Genetic diversity in plants. Eds. Çalişkan M. Croatia : 15 - 28. https://doi.org/10.1007/ 978-953-510185-7.

González-Robles, A. Manzaneda, A.J. Bastida, J.M. Harvey, N. Jaime, R. Salido, T. Martínez, L.M. Fernández, A. Alcántara, J.M. \& Rey, P.J. (2016) : Development and characterization of microsatellite primers in the endangered Mediterranean shrub Ziziphus lotus (Rhamnaceae). Applications in Plant Sciences, 4(12): 4 p. https://doi.org/10.3732/apps.1600092. 
Guo, Y. Ni, Y. Kokot, S. (2016) : Evaluation of chemical components and properties of the jujube fruit using near infrared spectroscopy and chemometrics. Spectrochimica Acta Part A: Molecular and Biomolecular Spectroscopy, 153: 7986. https://doi.org/10.1016/j.saa.2015.08.006.

Hammia, M.K. Jdey, A. Abdelly, C. Majdoub, H. Ksouri, R. (2015): Optimization of ultrasound-assisted extraction of antioxidant compounds from Tunisian Ziziphus lotus fruits using response surface methodology. Food Chemistry, 184 : 80-89. https://doi.org/10.1016/j.foodchem.2015.03.047.

Hemalatha, T. \& Shanmugasundaram, P. (2010): Efficiency of DNA Marker Systems in Discriminating Cajanus cajan (L.) Millsp. and its Wild Relatives. Indian J. Plant Genet. Resour., 23(1): 93-99.

Jahier, J. Chevre, A.M. Delourme, R. Eber, F. Tanguy, A.M. (1992): Téchniques de cytogénétique végétale. Ed. Institut Technique de la Recherche Agronomique (INRA), Paris. 184 p.

Laamouri, A. Ammari, Y. Albouchi, A. Sghaier, T. Mguis, K. \& Akrimi, N. (2008) : Etude comparative de la croissance et du développement du système racinaire de trois espèces de jujubier en Tunisie. Geo-Eco-Trop., 32: 37- 46.

Lamare, A. \& Rao, S.R. (2015): Efficacy of RAPD, ISSR and DAMD markers in assessment of genetic variability and population structure of wild Musa acuminata colla. Physiol Mol Biol Plants, 21(3): 349-358. https://doi.org/10.1007/s12298015-0295-1.

Li, L. Peng, J.Y. \& Bai, R.X. (2009): Analysis of the Genetic Relationships in Chinese Ziziphus with SRAP Markers. Agricultural Sciences in China, 9(9): 1278-1284. https://doi.org/10.1016/S1671-2927(09)60217-0.

Liu, J. Liu, H. Ma, L. Wang, S. Gao, J. Li, Y. Wu, R. \& Panga, X. (2014): A Chinese jujube (Ziziphus jujuba Mill.) fruit-expressed sequence tag (EST) library: Annotation and EST-SSR characterization. Scientia Horticulturae, 165: 99-105. https://doi.org/10.1016/j.scienta.2013.10.033.

Liu, M.J. Zhao, Z.H. (2009): Germplasm resources and production of jujube in China. Acta Hort. (ISHS), 840: 25-32. https://doi.org/10.17660/ActaHortic.2009.840.1.

Liu, P. Liu, M.J. Zhao, Z.H. Liu, X.Y. Yang, L. \& Wu, Y.L. (2009): Agronomic diversity of Sour Jujube (Ziziphus acidojujuba) in China. Acta Horticultura, 840 :203-208. https://doi.org/10.17660/ActaHortic.2009.840.4

Ma, Q.H. Wang, G.X. \& Liang, L.S. (2011): Development and characterization of SSR markers in Chinese jujube (Ziziphus jujuba Mill.) and its related species. Scientia Horticulturae, 129: 597-602. https://doi.org/10.1016/j.scienta.2011.04.032.

Maraghni, M. Gorai, M. \& Neffati, M. (2010): Seed germination at different temperatures and water stress levels, and seedling emergence from different depths of Ziziphus lotus. South African Journal of Botany, 76: 453-459. https://doi.org/10.1016/j.sajb.2010.02.092.

Maraghni, M. Gorai, M. \& Neffati, M. (2011) : The Influence of Water-Deficit Stress on Growth, Water Relations and Solute Accumulation in Wild Jujube (Ziziphus lotus). Journal of Ornamental and Horticultural Plants, 1(2): 63-72.

Martins, S. Ribeiro DeCarvalho, C. \& Carnide, V. (2015): Assessing phenotypic diversity of Cucurbita portuguese germplasm. Agriculture \& Forestry, 61(1): 27-33. https://doi.org/10.17707/AgricultForest.61.1.03

Mei, Z. Zhang, X. Liu, X. Imani, S. \& Fu, J. (2017): Genetic analysis of Canarium album in different areas of China by improved RAPD and ISSR. C. R. Biologies, xxx: 8p. https://doi.org/10.1016/j.crvi.2017.09.006. 
Milbourne, D. Meyer, R. Bradshaw, J.E. Baird, E. Bonar, N. Provan, J. Powell, W. \& Waugh, R. (1997): Comparison of PCR-based marker systems for the analysis of genetic relationships in cultivated potato. Mol. Breeding, 3(2): 127-136. 10.1023/A: https://doi.org/1009649521009.

Mondini, L. Noorani, A. Pagnotta, M.A. (2009): Assessing Plant Genetic Diversity by Molecular Tools. Diversity, 1: 19-35. https://doi.org/10.3390/d1010019.

Moustafa, M.F. Hesham, A. Quraishi, M.S. \& Alrumman, S.A. (2016): Variations in genetic and chemical constituents of Ziziphus spina-christi L. populations grown at various altitudinal zonation up to $2227 \mathrm{~m}$ height. Journal of Genetic Engineering and Biotechnology, 14: 349-362. https://doi.org/10.1016/j.jgeb.2016.09.001.

Nasri-Ayachi, M.B. \& Nabli, M.A. (2009) : Floral Biology Study Of Ziziphus Lotus L. $\begin{array}{llll}\text { Acta Hort. } & \text { (ISHS) 340, 337-342. }\end{array}$ https://doi.org/10.17660/ActaHortic.2009.840.46

Nebih Hadj-Sadok, D. Hadroug, S. \& Taoussi, F. (2014): Activité nématicide in vitro des extraits aqueux des plantes médicinales «Artemisia campestris, Ziziphus lotus, Datura stramonium et Urginea maritima » sur des larves de Meloidogyne. AFPP - Dixième conférence internationale sur les ravageurs en agriculture, Montpellier - 22 et 23 octobre 2014, 7 p.

Norouzia, E, Erfani-Moghadama, J, Fazelib, A, \& Khadivic, A (2017): Morphological variability within and among three species of Ziziphus genus using multivariate $\begin{array}{llll}\text { analysis. } & \text { Scientia } \quad \text { Horticulturae, 22: }\end{array}$ https://doi.org/10.1016/j.scienta.2017.05.016.

Nudin, N.F.H. Ali, A.M. Ngah, N. Mazlan, N.Z. Mat, N. AbdGhani, M.N. Alias, N. Zakaria, A. \& Jahan, M.S. (2017): ISSR marker-assisted genetic diversity analysis of Dioscorea hispida and selection of the best variety for sustainable production. C. R. Biologies, xxx: 8p. https://doi.org/10.1016/j.crvi.2017.08.003.

Oliet, J.A. Artero, F. Cuadros, S. Pue'rtolas, J. Luna, L. \& Grau, J.M. (2012): Deep planting with shelters improves performance of different stocktype sizes under arid Mediterranean conditions. New Forests, 43: 925-939. https://doi.org/10.1007/s11056-012-9345-5.

Prates, J. (2014): NZY Plant/Fungi gDNA Isolation kit. Nzytech genes \& enzymes. 6 p.

Prevost, A. \& Wilkinson, M.J. (1999): A new system of comparing PCR primers applied to ISSR fingerprinting of potato cultivars. Theor App Genet., 98:107-112. https://doi.org/10.1007/s001220051046.

Quezel, P. \& Santa, S. (1963): Nouvelle flore de l’Algérie et des régions désertiques méridionales. Tome II. Éditions du CNRS (Centre National de la Recherche Scientifique), Paris 7, 1170 p.

Rais, C. Lazraq, A. Houhou, M. Elhanafi, L. Fennane, A. Ghadraoui, L. Mansouri, I. Louahlia, S. (2017): Morphometrics and morphological comparative study of three natural populations of Ziziphus Lotus. Research Journal of Pharmaceutical, Biological and Chemical Sciences, 8(1): $1558 \quad$ - 1564. https://www.researchgate.net/publication/323946561.

Rashidi, M. Farshadfar, M. Safari, H. \& Shirvani, H. (2013): Utility of ISSR molecule marker in examine of genetic diversity 17 genotypes of perennial alfalfa (Medicago sativa). Journal of Novel Applied Sciences, 2(2S) : 969-973.

Regehr, D.L. \& El Brahli, A. (1995): Wild Jujube (Ziziphus lotus) Control in Morocco. Weed Technology, 9(2): 326-330. https://doi.org/10.1017/S0890037X00023423 
Riaz, A. Hameed, H. Khan, A.I. Younis, A. \& Awan, F.S. (2011): Assessment of biodiversity based on morphological characteristics and RAPD markers among genotypes of wild rose species. African Journal of Biotechnology, 10(59): 1252012526. https://doi.org/10.5897/AJB11.866.

Saran, P.L. (2005): Studies on genetic divergence in ber (Ziziphus mauritiana lamk.) Germplasm. Department of horticulture College of agriculture ccs haryana agricultural university, 178 p. (PhD thesis)

Sehgal, D. Rajpal, V.R. Raina, S.N. Sasanuma, T. \& Sasakuma, T. (2009): Assaying polymorphism at DNA level for genetic diversity diagnostics of the safflower (Carthamus tinctorius L.) world germplasmresources. Genetica, 135: 457-470. https://doi.org/ 10.1007/s10709-008-9292-4.

Seigne, A. (1985) : La forêt circum méditerranéenne et ses problèmes : Techniques Agricoles et Productions Méditerranéennes. Eds. G.P. Maisonneuve et Larose, Paris, pp : 137-141.

Singh, A.K. Devanshi, Sharma, P. Singh, R. Singh, B. Koundal, K.R. \& Singh, N.K. (2007): Assessment of Genetic Diversity in Ziziphus mauritiana Using InterSimple Sequence Repeat Markers. J. Plant Biochemistry \& Biotechnology, 16(1): 35-40. https://doi.org/10.1007/BF03321926.

Singh, S.K. Meghwal, P.R. Pathak, R. \& Gautam, R. (2014): Molecular Markers Assisted Identification of Intraspecific Hybrids in Ziziphus mauritiana. Proc. Natl. Acad. Sci., India, Sect. B Biol. Sci., 84(3): 603-611. https://doi.org/10.1007/s40011-0140336-5.

Sudhersan, C. \& Ashkanani, J.H. (2009): Introduction, evaluation and propagation of Ziziphus In Kuwait. Acta Hort. (ISHS) 840, 47-54. https://doi.org/10.17660/ActaHortic.2009.840.4

Tatari, M. Ghasemi, A. \& Mousavi, A. (2016): Genetic diversity in Jujube germplasm (Ziziphus jujuba Mill.) based on morphological and pomological traits in Isfahan province, Iran. Crop Breeding Journal, 4, 5 and 6 : 79-85. https://doi.org/ 10.22092/CBJ.2016.107110.

Tirado, R. \& Pugnaire, F.I. (2005) : Community structure and positive interactions in $\begin{array}{llll}\text { constraining environments. OIKOS, } 111 & \text { (3): } 437-444 .\end{array}$ https://doi.org/10.1111/j.1600-0706.2005.14094.x.

Tonk, F.A. Tosun, M. Ilker, E. Istipliler, D. \& Tatar, O. (2014): Evaluation and comparison of issr and rapd markers for assessment of genetic diversity in triticale genotypes. Bulgarian Journal of Agricultural Science, 20(6): 1413-1420.

Varshney, R.K. Chabane, K. Hendre, P.S. Aggarwal, R.K. Graner, A. (2007): Comparative assessment of EST-SSR, EST-SNP and AFLP markers for evaluation of genetic diversity and conservation of genetic resources using wild, cultivated and elite barleys. Plant Sci., 173(6): 638-649. https://doi.org/10.1016/j.plantsci.2007.08.010.

Wang, B. Huang, Q. Venkitasamy, C. Chai, H. Gao, H. Cheng, N. Cao, W. Lu, X. \& Pan, Z. (2016): Changes in phenolic compounds and their antioxidant capacities in jujube (Ziziphus jujuba Miller) during three edible maturity stages. LWT - Food Science and Technology, 66: 56 - 62. https://doi.org/10.1016/j.lwt.2015.10.005.

Wojdyło, A. Carbonell-Barrachina, A.A. Legua, P. \& Hernández, F. (2016): Phenolic composition, ascorbic acid content, and antioxidant capacity of Spanish jujube (Ziziphus jujube Mill.) fruits. Food Chemistry, 201: 307-314. https://doi.org/10.1016/j.foodchem.2016.01.090.

Zhang, Z. Gao, J. Kong, D. Wang, A. Tang, S. Li, Y. \& Pang, X. (2015): Assessing genetic diversity in Ziziphus jujuba 'Jinsixiaozao' using morphological and microsatellite (SSR) markers. Biochemical Systematics and Ecology, 61: 196 202. https://doi.org/10.1016/j.bse.2015.06.021 